\title{
Research Paper Post-harvest losses of alphonso mango in South Konkan region- An economic analysis
}

See end of the paper for authors' affiliations

Correspondence to :

P. J. Kshirsagar

Department of Agricultural Economics, College of Agriculture, Dr. B.S. Konkan Krishi Vidyapeeth, Dapoli (M.S.) India Email : sagartarang@ rediffmail.com
Paper History :

Received : 26.09.2018; Revised : 02.02.2019;

Accepted : 13.02.2019
ABSTRACT : The research study was carried out in South Konkan region of Maharashtra during year 2017-18 by following the simple random sampling of 100 respondents from 20 villages of two districts namely Ratnagiri and Sindhudurg and 50 intermediaries were selected from study area. The data was elicited through personal interview method. The findings revealed that, the average quantity of alphonso mango passed by the average individual farmers through channel-I was $23.02 \mathrm{q}$, channelII, 63.09 q, channel-III 9.16q, channel-IV 5.93q, channel-V 7.89q in the study area. In channel-I the total post-harvest losses in alphonso mango was found to be 27.88 per cent, in channel-II 25.41 per cent, in channel-III 7.07 per cent, in channel-IV, 15.63 per cent and channel-V 22.31 per cent. The average overall post-harvest losses in alphonso mango from field level to marketing level including all marketing operations estimated to 32.29 per cent. In monetary term, at individual farmer level, the total of Rs. 1.37 lakh had been estimated as post-harvest losses, out of that Rs. 0.46 lakh losses were accounted at field level of individual farmer and Rs. 0.91 lakh of losses were accounted at performing various marketing activities. In case of average marketing intermediaries' level, the total loss in alphonso mango accounted to Rs. 1.99 lakh and out that Rs. 1.53 lakh was loosed during marketing activities.

KEY WORDS : Economic analysis, Farm, Grading, Mango, Marketing, Post- harvest losses

How To Cite This PAPer : Kshirsagar, P.J., Shigawan, S.M., Wadkar, S.S. and Naik, V.G. (2019). Post-harvest losses of alphonso mango in South Konkan region- An economic analysis. Internat. Res. J. Agric. Eco. \& Stat., 10 (1) : 90-95, DOI : 10.15740/HAS/IRJAES/10.1/90-95. Copyright@ 2019: Hind Agri-Horticultural Society. 